\title{
OPEN
}

\section{Author Correction: Diversity of gut microflora is required for the generation of B cell with regulatory properties in a skin graft model}

R. Alhabbab, P. Blair, R. Elgueta, E. Stolarczyk, E. Marks, P. D. Becker, K. Ratnasothy, L. Smyth, N. Safinia, E. Sharif-Paghaleh, S. O'Connell, R. J. Noelle, G. M. Lord, J. K. Howard, J. Spencer, R. I. Lechler \& G. Lombardi

Correction to: Scientific Reports https://doi.org/10.1038/srep11554, published online 25 June 2015

This Article contains an error in the affiliations for R. Alhabbab, where 'Centre of Immunology, Division of Applied Medical Sciences, King Abdulaziz University, KSA' is incorrectly listed as a current address. The correct affiliations appear below:

Centre of Immunology, Division of Applied Medical Sciences, King Abdulaziz University, KSA.

Medical Research Council Centre for Transplantation, King's College London, King's Health Partners, Guy's Hospital, London, SE1 9RT, UK.

\begin{abstract}
(c) Open Access This article is licensed under a Creative Commons Attribution 4.0 International (c) License, which permits use, sharing, adaptation, distribution and reproduction in any medium or format, as long as you give appropriate credit to the original author(s) and the source, provide a link to the Creative Commons license, and indicate if changes were made. The images or other third party material in this article are included in the article's Creative Commons license, unless indicated otherwise in a credit line to the material. If material is not included in the article's Creative Commons license and your intended use is not permitted by statutory regulation or exceeds the permitted use, you will need to obtain permission directly from the copyright holder. To view a copy of this license, visit http://creativecommons.org/licenses/by/4.0/.
\end{abstract}

(C) The Author(s) 2020 